\title{
A TANULÓK EGYÜTTMÜKÖDÉSI SZINTJEINEK MEGHATÁROZÁSA TÁRSAS TEVÉKENYSÉGEK SORÁN
}

\author{
DOBOSNÉ FÖLDI BRIGITTA \\ Eszterházy Károly Egyetem
}

Neveléstudományi Doktori iskola

A tanulmány első részében, a pedagógusok nézeteit vizsgáltam a kooperatív tanulással kapcsolatban, és arra kérdésre kerestem a választ, hogy az elmúlt évek során beépültek-e ezen technikák a pedagógiai gyakorlatba. Az eredmények rávilágítottak arra, hogy a tanárok jelentős mértékben alkalmazzák óráikon a kooperatív tanulást, és fontosnak tartják a társas készségek fejlesztését. A kutatás másik része a tanulók együttműködési szintjeire irányult. A vizsgálat rámutatott arra, hogyan jellemezhetők azok a diákok, akik alacsony, átlagos vagy magas szintű együttműködési képességgel rendelkeznek. Az eredmények jól látható eltéréseket mutatnak, amelyeket érdemes lenne egy újabb, magasabb mintaszámú kutatással kibővíteni.

\section{Bevezetés}

A pedagógiai munka során egyre több olyan módszert, tanulásszervezési eljárást alkalmaznak a tanítók, tanárok, oktatók, amelyek lehetővé teszik a tanulók társas készségeinek fejlődését. A család után az iskola a legfontosabb szocializációs színtér, ezért a pedagógusok szerepe kiemelt helyen áll a tanulók szociális készségeinek fejlesztésében. Napjainkban a munkaerőpiac számos olyan készséget vár el az alkalmazottaktól, amelyek nem szakmai jellegűek, sokkal inkább a teammunkához, kooperációhoz, a szervezeten belüli közös alkotáshoz kapcsolódnak (Dobosné, 2017). A magasabb szintű szociális készségekkel rendelkező emberek hatékonyabban tudnak együtt dolgozni, és ezáltal eredményesebb munkavégzésre képesek (Deming, 2017). Longitudinális vizsgálatok erős korrelációt állapítottak meg az óvodáskorúak körében mért szociális érzelmi kompetencia és a későbbi felnőtt lét egyes területei között, mint például a munkavállalás, a keresetek és az egészség (Dodge és mtsai., 2014; Jones, Greenberg, and Crowley, 2015). Rendkívül fontos, hogy már óvodáskorban, majd később az általános és középiskolákban is segítsük a diákokat a proszociális viselkedés kialakításában. A társas készségek közül az együttműködésre nevelés különös jelentőséggel bír, hiszen a legtöbb szakma szükségszerűnek tartja e készség magas fejlettségi szintjét (Dobosné, 2017). 


\section{A társas készségek fejlesztése és a mérés problematikája}

A szociális kompetencia vizsgálatára és mérésére már hazai (Zsolnai és Kasik, 2010; Böddi, 2019) és nemzetközi (Spence, 1983; Goleman, 1995; Fiske, 2006; Denham és mtsai., 2004) viszonylatban is több kutató vállalkozott, köszönhetően a 20. század közepétől megjelenő új neveléstudományi trendeknek. Kutatások igazolják (Nagy, 2000, 2007, 2010; Zsolnai, 2019), hogy a szociális készségek fejlesztése gyermekkorban legalább annyira fontos, mint a kognitív képességeké, ezért az iskolákban mára már több olyan módszert, tanulásszervezési eljárást (pl.: kooperatív tanulás, drámapedagógiai eszközök, beszélgetőkör stb.) alkalmaznak a pedagógusok, melyekkel elősegítik a társas készségek fejlődését. A NAT kulcskompetenciái között találjuk a személyes és társas kapcsolati kompetenciákat (NAT, 2020), ami tükrözi a téma fontosságát, korszerűségét.

Arról azonban, hogy valójában az egyes életkorokban milyen eltérések tapasztalhatóak, és hogyan tudjuk pontosan jellemezni a tanulók szociális kompetenciájának fejlettségét, kevés adat áll rendelkezésünkre. Néhány vizsgálat (Zsolnai és Józsa, 2002; Józsa és Zsolnai, 2005), melyeket 8-10, valamint 11-13 éves tanulók körében végeztek, azonban rávilágított arra, hogy a szociális készségek nem vagy alig fejlődnek spontán módon ezekben az életszakaszokban, és a későbbi életkorokban, 14-16 éveseknél sincs számottevő különbség (Zsolnai, 1999; Kasik, 2006). Ezért rendkívül fontos a korai intervenció (Böddi, 2019).

A társas készségek vizsgálatánál a legfőbb gondot az okozza, hogy kevés az olyan mérőeszköz, amellyel pontosan tudjuk jellemezni a társas készségeket. A szociális kompetencia mérésére alkalmazott egyik legelterjedtebb technika az interjú. Interjút készíthetünk a vizsgált személlyel vagy az őt jól ismerő emberekkel (pl.: szülő, barát, pedagógus). Kisgyermekkorban a bábokkal történő kikérdezés az egyik legkedveltebb módszer, melyet Ablow és Measelle dolgozott ki (Semrud-Cikleman, 2007). Mérőskálák is rendelkezésünkre állnak, amelyekkel főleg a problémás szociális magatartást jellemezhetjük. Egy másik, a szociális készségek mérésére alkalmas módszer az önjellemzés, amely többféle lehet, de a legtöbb kutató a kérdőíves formát alkalmazza. A Gresham és Elliot (1993) által kidolgozott Social Skills Rating Scale a szociális készségeket direkt vizsgáló eszköz. A naplókat, önmegfigyeléseket kevésbé használják gyerekek körében szociális kompetencia mérésére. A természetes környezetben történő megfigyelés különféle helyzetekben, szituációkban (Gottman, 1977) szintén az alkalmazott technikák közé sorolandó. Napjainkban mégis az egyik legelterjedtebb módszer a Moreno által kifejlesztett szociometriai mérés, amelyet hazánkba Mérei Ferenc vezetett be (Mérei, 2006). Kétféle formája létezik: a választás és az értékelés. Az első részben csak azt kell megjelölniük a gyerekeknek, akit pl. a legjobban vagy legkevésbé kedvelnek az osztályban, a második mérésben viszont értékelniük is kell társaikat. Azonban meg kell jegyeznünk, hogy a szociometriai mérés, valamint a szociális 
készségek fejlettségi szintjének megállapítása közé nem tehető egyenlőségjel. Fontos lenne olyan mérőeszközök kidolgozása, amelyek a pedagógusok számára könnyen elérhetőek, és a mindennapi gyakorlatban is jól használhatóak.

Elmondható, hogy sok eszköz áll rendelkezésünkre a szociális kompetencia mérésére, viszont kutatások bizonyítják azt is, hogy a kognitív képességeket vizsgáló mérések reliabilitása és validitása sokkal magasabb szinten áll, mint a szociális készségek vizsgálatára használt módszereké (Semrud-Cikleman, 2007). Ennek fö oka, hogy a szociális készségek és képességek mérését sokféle tényező nehezíti. A szociális viselkedés mindig szituációhoz kötött, ami hatással van a mérés objektivitására. Ugyanakkor az is nehezítő körülmény, hogy másként ítélheti meg a tanuló, szülő és pedagógus az adott szociális készség fejlettségét (Zsolnai, 2019).

\section{Együttmüködés}

Az együttműködés meghatározása nem könnyü feladat. Bakos (1967) szerint a következőképpen foglalható össze a kooperáció, vagyis együttműködés fogalma: (1) együttmüködés, közremüködés, összedolgozás, (2) segitség, támogatás, (3) szövetkezés (Bakos, 1967, 392. o.). „Az együttmüködés együttes munkálkodást jelent. Ideális esetben az együttmüködés egyenrangú partnerek közt jön létre, akik közös cél elérésén munkálkodnak. A célt vagy maguk a résztvevök fogalmazzák meg, vagy kivülröl tüzik eléjük. Az együttmüködö partnereknek saját elgondolásaik, érdekeik és igényeik vannak, és mindezt magukkal tudják hozni a csoportba. De mások elgondolásait, érdekeit és igényeit is figyelembe tudják venni, és kompromisszumokat tudnak kötni. Az együttmüködés folyamat, amelyet az embereknek mindig újból és újból végig kell csinálniuk, hogy olyan eredményre jussanak, amelyet az egyes ember egyedül nem érhet el." (Jamie Walker, 1995. 112. o.) Nagy József az iskola egyik legkiemeltebb feladataként határozza meg a proszociális együttműködési képesség fejlesztését, melynek az egyik leghatékonyabb formája a kooperatív tanulási tevékenységek szervezése az iskolai élet minél több területén (Nagy, 2000). A hatékony együttműködés szintjeit Némethné (2008) a következőképpen csoportosítja:

1. Alapszint: konstruktív ötletekkel hozzájárul a munkához; aktívan vesz részt a csoport munkájában; elfogadja a felajánlott segítséget.

2. Középszint: segít másoknak, ha kell, elfogadja a tevékenységére irányuló kritikát, és annak alapján módosítja azt; önként, szívesen vállal szerepet vagy a csoport által meghatározott feladatot; a csoport feladatának befejezéséig folytatja a munkát.

3. Emelt szint: hasznos ötletekkel és javaslatokkal segíti a csoportmunkát; érzékeny a csoporttagok igényeire vagy korlátaira mind a saját szerepének vagy feladatának meg- 
választásában, mind azok csoporton belüli megosztásában; vezetői készségeket mutat a választott szerepben, a tevékenységek koordinálásában; szívesen elvállalja a csoport által kijelölt szerepeket (Némethné, 2008).

Összességében elmondható, hogy az együttműködés közös tevékenységek során létrejövő együttes munkálkodás, amely épít a tanulók saját elgondolásaira, ugyanakkor arra sarkallja őket, hogy egy közös cél érdekében megpróbáljanak együtt dolgozni, és olyan eredményeket elérni, amelyeket egyedül nem sikerülhetne megvalósítaniuk.

\section{A kooperatív csoportmunka mint a tanulói együttmúködés színtere}

A kooperatív tanulás „összehangolt tevékenység, amely során kölcsönös a hatás pszichikai, szociális és intellektuális készségek fejlödésében egyaránt" (Horváth, 1994, 17.o.). Kölcsönös, pozitív függést jelent, valamint feltételezi a szociális érzékenységet, szociális késségek meglétét. Nagy szerepe van a tanulói önállóságnak, az önálló tanulásnak és az együttműködésen alapuló tanulásnak (Bárdossy, 1999). Olyan folyamat, ahol együtt tanulva, összevetve a saját ismeretinket másokéval, a többiek és a tanár által ösztönözve lehetséges tanulni. A pedagógusoknak a diákokat együttműködő partnereknek kell tekinteni, és bízni kell a tanulók „tanári képességeiben” és abban, hogy megfelelő, szolidáris légkörben képesek lesznek egymás tanárai lenni (Orbán, 2009). A kooperatív tanulás lehetőséget teremt arra, hogy a tanulók együttműködésre, kölcsönös felelösségre alapozva sajátítsák el a tananyagot, miközben szociális ismeretekre is szert tesznek. A kooperatív csoportmunka feltétele az együttműködés, ezért alkalmas lehet arra, hogy megfigyeljük a tanulók társas készségeit, és segítségével megvizsgáljuk a tanulók együttmüködési képességének eltérő szintjeit.

\section{A kutatás célja}

Kutatásom fókuszába az együttműködés vizsgálatát helyeztem, kooperatív és egyéb társas tanórai tevékenység során. Elsőként arra kerestem a választ, hogy a pedagógusok mennyire ítélik fontosnak a kooperativitást tanóráikon, és használnak-e olyan tanulásszervezési eljárásokat, amelyek pozitívan hatnak a tanulók együttmüködésének fejlődésére. Kíváncsi voltam arra is, hogy a pedagógusok hogyan ítélik meg az általános iskolába járó diákok együttműködését, milyen szintbeli különbségeket látnak az alacsony, átlagos és magas együttmüködési készséggel rendelkező tanulók között. Hogyan vesznek részt az egyes diákok a kooperatív tanulásban vagy egyéb tanórai társas helyzetekben? Mindezek alapján meg lehet-e fogalmazni olyan jellemzőket, amelyek elkülönítik az egyes együttműködési 
szinteket? A kutatási kérdések legfőbb indoka az volt, hogy a szakirodalomban leginkább általános jellemzőket találhatunk, nem elkülönített együttműködési szinteket, pedig a pedagógustársadalomnak igen nagy szüksége volna olyan standardizált mérőeszközökre, amelyek segítik őket közelebbről megismerni a diákok szociális készségeit, pontosabb, árnyaltabb képet kaphatnának egy-egy tanuló vagy akár egy osztály társas készségeiről.

\section{A kutatás hipotézisei}

Kutatásom hipotéziseit a következő állításokban fogalmaztam meg. Feltételeztem, hogy: H1: A pedagógusok fontosnak ítélik meg a kooperatív csoportmunka alkalmazását munkájuk során.

H2: A pedagógusok az óráik jelentős részében alkalmaznak kooperatív technikákat.

H3: A pedagógusok megitélései alapján megfogalmazható különbség van az együttműködési készség szintjeiben.

H4: Elkülöníthető jellemzőket találunk az egyes együttműködési szintek között.

\section{Minta és módszer}

A vizsgálati minta kiválasztása hólabdaszerű mintavételi eljárással történt, ami a reprezentativitás növelése érdekében fontos kritérium. Korlátja a kutatásnak, hogy a valószínűségi mintavétel ellenére sem sikerült a nagy mintaszám elérése, arra azonban alkalmasnak bizonyult, hogy megfigyelhessünk jellemzőket, különféle mintázatokat. A vizsgálati mintába összesen $\mathrm{N}=22$ fö került, akik általános iskolában dolgozó pedagógusok. Kifejezetten az általános iskolai tanárok nézeteire voltam kíváncsi a témában, mivel előzetes kutatásaim alapján kimutatható volt, hogy az általános iskolában jelentős változások figyelhetőek meg a társas készségek fejlődése terén, ami a középiskolában már kisebb mértékủ (Dobosné, 2019). Felhasznált módszerként online kérdőívet alkalmaztam, többségében nyílt végü kérdésekkel, ahol a pedagógusoknak kellett megfogalmazniuk az együttműködési szintekkel kapcsolatos nézeteiket. Példák a kérdőívben található kérdésekre: 1. Fejezze be a következö mondatot! Az a tanuló, aki alacsony együttmüködési készséggel rendelkezik...; 2. Írjon további három állitást arról, hogyan jellemezhetöek azok a diákok, akik magas szintü együttmüködést mutatnak a csoportmunka vagy más társas tevékenység során!; 3. Fogalmazza meg, mit jelent Ön számára az együttmüködés a tanulók között kooperativ csoportmunka során! 


\section{Eredmények}

A vizsgálat fókuszában az együttműködési készség szintjeinek meghatározása állt a kooperatív vagy más társas tevékenységek folyamán. A kutatásban használt online kérdőívet 22 fö pedagógus töltötte ki. A kitöltők mindegyike általános iskolában dolgozó tanár és tanító volt. 54\% alsó tagozaton, 34\% felső tagozaton és 14\% mindkét tagozaton tanító pedagógus.

A kutatás első felében felmértem a pedagógusok nézeteit a kooperatív csoportmunkával kapcsolatban. Kíváncsi voltam, milyen mértékben alkalmaznak a tanórákon kooperatív technikákat. (1. ábra) A válaszadók 59\%-a nyilatkozott arról, hogy gyakran, 32\% általában, és mindössze $9 \%$ volt, aki soha vagy csak néha használ kooperatív módszert pedagógiai gyakorlatában. Ez az adat azért nagyon jelentős, mert arról ad tanúbizonyságot, hogy a kooperativitás mára már beépülni látszik a pedagógusok módszertárába.

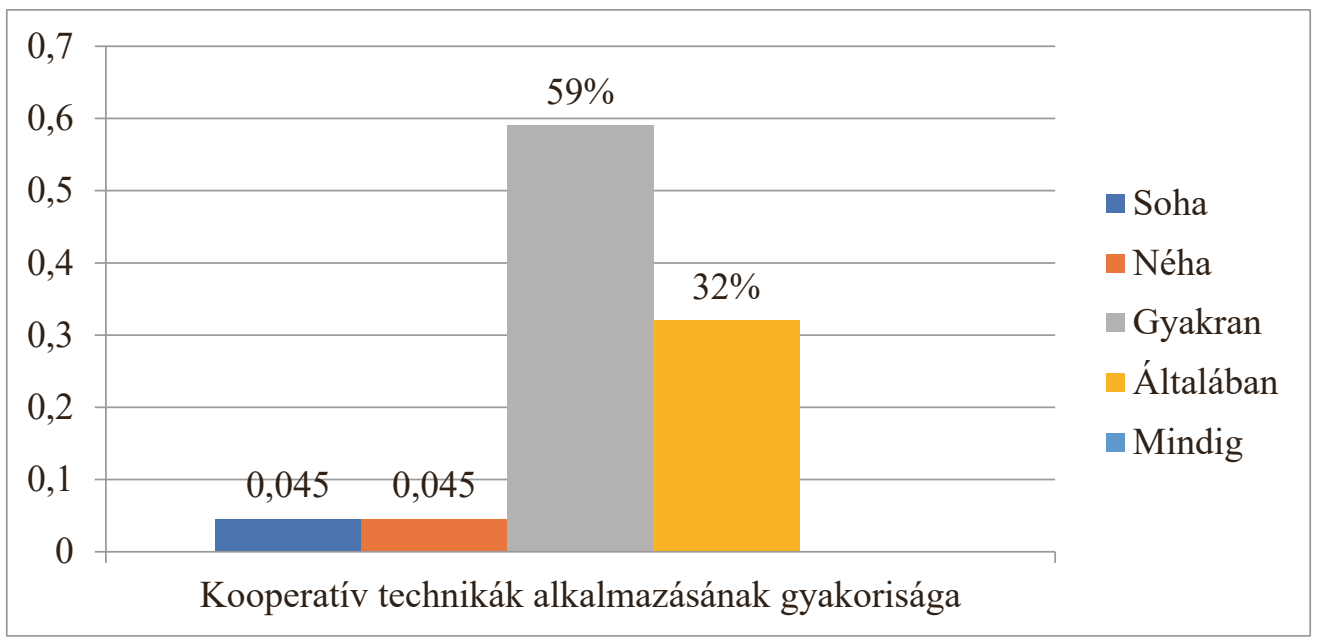

1. ábra. Kooperativ technikák alkalmazásának gyakorisága a tanórákon

A vizsgálatban kitértem arra is, hogy mennyire ítélik fontosnak a társas készségek fejlesztését munkájuk során a pedagógusok. Az eredmények azt mutatják, hogy a tanárok egyetértenek abban, hogy az együttműködésre nevelés és a társas készségek fejlesztése kiemelt feladat. A válaszadók 60\%-a teljes mértékben, 40\%-a inkább fontosnak ítélte meg munkájában a szociális készségek fejlesztését. Az „egyáltalán nem tartja fontosnak”, „kevésbé tartja fontosnak" és a "fontosnak is tartja, meg nem is" kategóriákat senki sem jelölte válaszként. Szerettem volna választ kapni arra a kérdésre, mit értenek a pedagógusok együttműködés alatt a kooperatív csoportmunka vagy egyéb társas tanórai tevékenység során. A kapott válaszokat csoportosítottam aszerint, hogy milyen gyakorisággal fordultak elő a pedagógusok válaszaiban. A 1. táblázatban látható az eredmények összegzése: 


\begin{tabular}{|c|c|}
\hline Együttmúlködés meghatározása a pedagógusok válaszai alapján $\mathrm{N}=22$ & gyakoriság (Fő) \\
\hline egymás segítése & 11 \\
\hline közös munka & 9 \\
\hline közös cél elérése & 7 \\
\hline hatékony, közös kommunikáció & 7 \\
\hline elfogadás & 4 \\
\hline együtt gondolkodás & 4 \\
\hline támogatás & 2 \\
\hline összefogás & 2 \\
\hline társas készségek fejlődése & 2 \\
\hline $\begin{array}{l}\text { Egyéb válaszok, melyeket } 1-1 \text { fö említett: } \\
\text { kompromisszumkészség } \\
\text { vitakultúra } \\
\text { kritikai gondolkodás } \\
\text { empátia } \\
\text { odafigyelés } \\
\text { alkalmazkodás } \\
\text { tudásmegosztás } \\
\text { egymásra figyelés }\end{array}$ & 1 \\
\hline
\end{tabular}

\section{1. táblázat. Együttmüködés meghatározása a pedagógusok szemszögéböl}

A kapott válaszok alapján kijelenthető, hogy az együttműködés közös munkálkodást, gondolkodást jelent, valamely közös cél elérése érdekében, miközben a tanulók folyamatosan segítik egymást, kommunikálnak, alkalmazkodnak, elfogadják egymás ötleteit, tudást osztanak meg, támogatják egymást.

A táblázatban látható, hogy a pedagógusok megítélése szerint az együttműködés egyik legfontosabb ismérve a segítés, ugyanakkor az is megfigyelhető, hogy a közös munka, az összefogás, a közös gondolkodás, a kommunikáció és a közös célok mind olyan jellemzők, amelyek nélkül nem képzelhető el hatékony együttműködés. A pedagógusok több jelzővel tudták körülírni az együttműködést, ami alapján kiemelhetjük, hogy meghatározása nagyon sokrétü, rengeteg attitűdöt, készséget, jellemzőt foglal magában.

A kutatás fókuszába került az együttműködési szintek meghatározása. A pedagógusok sokféle választ írtak arra vonatkozóan, mi jellemzi az alacsony, átlagos és magas együttműködési képességgel rendelkező diákokat. Az alábbiakban példákat sorolok fel a teljesség igénye nélkül a kapott válaszokból.

- Alacsony szintü együttmüködés:

"Kevésbé motiválható a közös munka elvégzésére."

"Inkább egyedül, elszigetelten dolgozik; nehezebben teremt kapcsolatokat.” 
"Önállótlan, vagy önzö magatartást mutat. Beleérzö képessége fejletlen, nem érti a körülötte lévô embereket, igényeit nehezen fejezi ki, a segitségre szoruló társait nem vagy nehezen érzékeli."

- Átlagos szintủ együttműködés:

"Részt vesz csoportmunkában, de abban kevésbé kezdeményezö."

„Segitséggel tud jól csapatban együtt dolgozni. Általában nem vezetö személyiségek."

"Hasznos tagja a csapatnak, jó munkaerö."

- Magas szintű együttműködés:

„Megkönnyíti a közös feladaton dolgozók munkáját, és motiváló erö a társainak."

"Irányítani tudja a csoportot."

"Hatékonyan képes a tudásával támogatni a célt, nyitott a társaitól kapott információk beépitésére, felhasználására."

A kapott válaszok alapján megpróbáltam egy táblázatba (3. táblázat) foglalni, hogyan jellemezhetőek a különböző együttműködési szinttel rendelkező általános iskolás diákok, hogyan vesznek részt a társas tevékenységekben, csoportmunkában, mi jellemzi őket. A tanárok megfogalmazásaiból kitűnt, hogy az egyes szintek jellemzői jól elkülöníthető képet mutatnak. Az egyes mondatok megjelentek a különböző együttműködési szinteken, más-más megfogalmazásban, ahhoz mérten, hogyan viselkednek, mi jellemzi a tanulókat, miként vesznek részt a közös feladatokban, milyen eltérések vannak közöttük a vizsgált képesség terén.

\begin{tabular}{|l|l|l|}
\hline \multicolumn{2}{|c|}{ Együttmüködési szintek jellemzői } \\
\hline \multicolumn{1}{|c|}{ Alacsony } & \multicolumn{1}{c|}{ Átlagos } & \multicolumn{1}{c|}{ Magas } \\
\hline $\begin{array}{l}\text { kevésbé vagy egyáltalán nem } \\
\text { motiválható a közös munkára }\end{array}$ & $\begin{array}{l}\text { könnyen motiválható a közös } \\
\text { munkára }\end{array}$ & $\begin{array}{l}\text { könnyen motiválható, és moti- } \\
\text { váló erö társai számára }\end{array}$ \\
\hline $\begin{array}{l}\text { nehezen boldogul a közös } \\
\text { munkában }\end{array}$ & jól boldogul a közös munkában & $\begin{array}{l}\text { könnyen boldogul a közös } \\
\text { munkában }\end{array}$ \\
\hline $\begin{array}{l}\text { elszigetelödik, vagy olykor } \\
\text { hátráltatja csoport munkáját }\end{array}$ & segíti a csoport munkáját & megkönnyíti társai munkáját \\
\hline $\begin{array}{l}\text { nehezen lép interakcióba, } \\
\text { olykor rendbontásra használja } \\
\text { a kommunikációt }\end{array}$ & $\begin{array}{l}\text { jól kommunikál, meghallgatja } \\
\text { mások véleményét }\end{array}$ & $\begin{array}{l}\text { fejlett kommunikációs kész- } \\
\text { séggel rendelkezik, hatékonyan } \\
\text { kommunikál társaival }\end{array}$ \\
\hline $\begin{array}{l}\text { önállótlan, nehezen } \\
\text { kezdeményez }\end{array}$ & $\begin{array}{l}\text { részt vesz a csoportmunkában, } \\
\text { kevésbé kezdeményez }\end{array}$ & $\begin{array}{l}\text { könnyen kezdeményez, irányítja } \\
\text { a csoport munkáját }\end{array}$ \\
\hline $\begin{array}{l}\text { nem fejezi ki saját és/vagy nem } \\
\text { fogadja el mások véleményét }\end{array}$ & $\begin{array}{l}\text { képes mások véleményének } \\
\text { elfogadására }\end{array}$ & $\begin{array}{l}\text { mások véleményét elfogadja, } \\
\text { képes a másoktól kapott infor- } \\
\text { máció beépítésére }\end{array}$ \\
\hline $\begin{array}{l}\text { nem vagy nehezen } \\
\text { alkalmazkodik }\end{array}$ & jól alkalmazkodik & $\begin{array}{l}\text { könnyen alkalmazkodik minden } \\
\text { új helyzethez és társaihoz }\end{array}$ \\
\hline
\end{tabular}




\begin{tabular}{|l|l|l|}
\hline \multicolumn{2}{|c|}{ Együttmüködési szintek jellemzői } \\
\hline \multicolumn{1}{|c|}{ Alacsony } & \multicolumn{1}{c|}{ Átlagos } & \multicolumn{1}{c|}{ Magas } \\
\hline $\begin{array}{l}\text { érdektelen, vagy kevésbé érdekli } \\
\text { a csoport sikere }\end{array}$ & érdekli a csoport sikere & $\begin{array}{l}\text { kiemelten fontos számára } \\
\text { a csoportmunka sikeressége }\end{array}$ \\
\hline $\begin{array}{l}\text { igényeit/érzelmeit nehezen fejezi } \\
\text { ki }\end{array}$ & $\begin{array}{l}\text { általában könnyen kifejezi } \\
\text { igényeit, érzelmeit }\end{array}$ & $\begin{array}{l}\text { nyitott, könnyen fejezi ki } \\
\text { érzelmeit }\end{array}$ \\
\hline $\begin{array}{l}\text { társai nem vagy kevésbé szívesen } \\
\text { dolgoznak vele }\end{array}$ & társai szívesen dolgoznak vele & $\begin{array}{l}\text { társai szívesen dolgoznak vele, } \\
\text { követik őt }\end{array}$ \\
\hline $\begin{array}{l}\text { nem vagy kevésbé segíti ötletei- } \\
\text { vel a csoportmunkát }\end{array}$ & jó ötletei vannak & $\begin{array}{l}\text { konstruktív ötletei vannak, } \\
\text { melyekkel segíti társait }\end{array}$ \\
\hline $\begin{array}{l}\text { nem vagy kevésbé képes } \\
\text { szabálykövetésre }\end{array}$ & szabálykövető & $\begin{array}{l}\text { szabálykövető, és sokszor társait } \\
\text { is erre bátorítja }\end{array}$ \\
\hline
\end{tabular}

2. táblázat. Az együttmüködés szintjeinek meghatározása, jellemzöi

A 2. táblázat alapján elmondható, hogy a pedagógusok válaszaiban fellelhetőek voltak olyan mintázatok, melyeknek köszönhetően sikerült elkülöníteni bizonyos jellemzőket, amelyek megtalálhatóak az együttműködési képesség egyes szintjein más-más formában. Az alacsony együttműködési szinten álló tanulók a csoportmunkában általában a perifériára szorulnak, kevésbé motiválhatóak, és nehezen kezdeményeznek, kommunikálnak társaikkal. Az átlagos együttműködési készséggel rendelkezők jellemzője, hogy általában jó munkaerők, alkalmazkodóak, képesek egymás elfogadására. A magas szinten együttműködő diákok rendelkeznek olyan „plusz” attitűdökkel, viselkedési repertoárral, jellemzőkkel, amelyek megkülönböztetik őket az átlagtól. Ilyenek például a vezetői készségek, a fejlett kommunikációs és kezdeményezőkészség és a csoportsiker fontosságának érzete. Következtetésként elmondható, hogy a tanulók együttmüködésének szintjei megkülönböztethetőek, jól elhatárolhatóak egymástól.

\section{Összegzés}

A kutatás célja annak felderítése volt, hogy a pedagógusok miként látják a tanulók együttmüködését a csoportmunka és társas tevékenységek során, hogyan építik be munkájukba a kooperatív tanulást, és mennyire tartják fontosnak a társas készségek fejlesztését. A hipotéziseim igazoltnak tekinthetők, hiszen a válaszadó pedagógusok $(\mathrm{N}=22)$ gyakran alkalmaznak kooperatív technikákat a tanórákon, és fontosnak ítélik meg a szociális készségek célzott fejlesztését is. A vizsgálat másik felében arra fókuszáltam, vajon hogyan képesek a pedagógusok megfogalmazni a csoportmunkák, társas tevékenységek során tapasztalt eltéréseket 
a tanulók együttműködésében, és ezen meghatározások alapján megkülönböztethetőek lesznek-e az együttműködési szintek (alacsony, átlagos, magas). A válaszok alapján jól elkülöníthető jellemzőket írtak le a tanárok a tanulók együttműködési szintjeiről. Összegeztem az eltéréseket az egyes szintekre vonatkozóan, és kifejtettem, hogyan jellemezték az egyes területeket (együttműködési szinteket) a válaszadó pedagógusok.

Következtetésként elmondhatjuk, hogy a kooperatív tanulás és más társas tevékenységek az elmúlt évek során beépültek a pedagógiai gyakorlatba, hiszen a pedagógusok nagy része használja őket, és kiemelten fontosnak tartja a társas készségek fejlesztését. Érdemes lenne a kutatást kiterjeszteni nagyobb mintaszámra más mintázatok, jellemzők megtalálása céljából, valamint megvizsgálni a különbségeket az alsó és felső tagozatos tanárok megítélései között. Így még pontosabb kép rajzolódna ki az általános iskolás diákok együttműködésének fejlettségi szintje között, jellemezhető lenne, hogyan változnak, gazdagodnak az együttmủködés elemei az egyes életkorokban.

\section{Felhasznált irodalom:}

Bakos Ferenc (1967): Idegen szavak és kifejezések szótára. Akadémiai Kiadó, Budapest. 392. o.

Bárdossy Ildikó (1999): A produktív tanulás főbb összetevői és feltételei, In: Kooperativ pedagógiai stratégiák az iskolában III. JPTE Tanárképző Intézete, Pécs, 20-21.

Böddi Zsófia (2019): Társas interakciók megfigyeléses vizsgálata integráló óvodai csoportokban. Gyermeknevelés: Online Tudományos Folyóirat, 7. 28-44. https://doi.org/10.31074/2019232844

Denham, S., von Salisch, M., Olthof, T., Kochanoff, A. és Caverly, S. (2004): Emotional and social development in childhood. In: Smith, P. K. és Hart, C. H. (szerk.): Blackwell handbook of childhood social development. Blackwell Publishing, London, 307-328.

Deming DJ. (2017): The Growing Importance of Social Skills in the Labor Market. Quarterly Journal of Economics, 132. 4. sz.1593-1640.

https://doi.org/10.1093/qje/qjx022

Dobosné Földi Brigitta (2017): Társas készségek vizsgálata a Noldus interakció elemző programmal. In: Kerülö Judit, Jenei Teréz, Gyarmati Imre (szerk.): XVII. Országos Neveléstudományi Konferencia: Program és absztrakt kötet. Nyíregyházi Egyetem, Nyíregyháza. 373.

Dodge, Kenneth A., Karen L. Bierman, John D. Coie, Mark T. Greenberg, John E. Lochman, Robert J. McMahon, and Ellen E. Pinderhughes (2014): Impact of Early 
Intervention on Psychopathology, Crime, and Well-Being at Age 25. American Journal of Psychiatry, 172. 59-70. https://doi.org/10.1176/appi.ajp.2014.13060786

Dobosné Földi Brigitta (2017): A szociális kompetencia megjelenése a pályaleírásokban, valamint a felsőoktatási képzési és kimeneti követelményekben. EDU Szakképzéspedagógia, 7. 2. 26-49.

Dobosné Földi Brigitta (2019): Az együttműködés vizsgálatának lehetősége egy video elemző szoftver segítségével. In: Éva, Borsos; Rita, Horák; Zsolt, Námesztovszki; Cintia Kovács (szerk.): A Magyar Tannyelvű Tanítóképző Kar tudományos konferenciáinak tanulmánygyűjteménye. Újvidéki Egyetem Magyar Tannyelvű Tanítóképző Kar, Szabadka, 310-319.

Fiske, S. T. (2006): Társas alapmotívumok. Osiris Kiadó, Budapest.

Gresham, F. M. és Elliott, S. N. (1993): Social skills intervention guide: Systematic approaches to social skills training. Special Services in the Schools, 8. 1. 37-158.

https://doi.org/10.1300/J008v08n01_07

Goleman, D. (1995): Emotional intelligence. Bantam Books, New York.

Gottman, J. M. (1977): Toward a definition of social isolation in children. Child Development, 48. 513-517. https://doi.org/10.2307/1128647

Horváth H. Attila (1994): Kooperativ technikák - Hatékonyság a nevelésben. Oki Iskolafejlesztési Központ, Budapest.

Jamie Walker (1995): Feszültségoldás az iskolában - Játékok és gyakorlatok. Nemzeti Tankönyvkiadó, Budapest.

Jones, Damon E., Mark Greenberg, and Max Crowley (2015): Early Social-Emotional Functioning and Public Health: the Relationship between Kindergarten Social Competence and Future Wellness. American Journal of Public Health, 105. 1-8. https://doi.org/10.2105/AJPH.2015.302630

Józsa Krisztián és Zsolnai Anikó (2005): Szociális készségek fejlödése a serdülökor kezdetén. V. Országos Neveléstudományi Konferencia, Budapest, 2005. október 6-9. Konferenciakötet, 115 .

Mérei Ferenc (2006): Közösségek rejtett hálózata. Osiris Kiadó, Budapest.

Nagy József (2000): XXI. század és nevelés. Osiris Kiadó, Budapest.

Nagy József (2007): Kompetenciaalapú kritériumorientált pedagógia. Mozaik Kiadó, Szeged. Nagy József (2010): Új pedagógiai kultúra. Mozaik Kiadó, Szeged.

Németh Gáborné Doktor Andrea (2004): A szociális kompetencia fejlesztésének lehetőségei az iskolában. Új Pedagógiai Szemle, 58. 4. 23-34.

Orbán Józsefné (2009): A kooperativ tanulás: szervezés és alkalmazás. Orbán \& Orbán Bt., Pécs. 
Semrud-Clikeman, M. (2007): Social competence in children. Springer, New York.

Spence, S. (1983): Developments in social skills training. Academic Press, London.

Zsolnai Anikó (1999): Összefüggések a szociális kompetencia egyes komponensei, a tanulási motivumok és az iskolai tudás között. JATE Press, Szeged.

Zsolnai Anikó és Józsa Krisztián (2002): A szociális készségek kritériumorientált fejlesztésének lehetőségei. Iskolakultúra, 12. 4. 12-20.

Zsolnai Anikó és Kasik László (2010, szerk.): A szociális kompetencia fejlesztésének elméleti és gyakorlati alapjai. Nemzeti Tankönyvkiadó, Budapest.

Zsolnai Anikó (2019): A szociális kompetencia fejlödése és fejlesztési lehetöségei gyermekkorban. Akadémiai doktori értekezés, Budapest.

http://real-d.mtak.hu/1136/7/dc_1503_17_doktori_mu.pdf Letöltve: 2020. november 29. 